\title{
The Pacific Medical Supply Workers Buddy Network: a regional professionalization activity
}

\author{
Ben Gilbert ${ }^{*}$, Andrew Brown ${ }^{2}$ \\ From The 2nd People that Deliver (2nd PtD) Global Conference on Human Resources in Supply Chain \\ Management \\ Copenhagen, Denmark. 29-30 October 2014
}

\section{Background}

Field experience, literature review and focus group findings indicated that a Buddy Network could help to overcome the unique barriers encountered by senior medical supply workers in Pacific Island Countries, including chief pharmacists, central medical store managers and country program managers. Specifically it could: encourage shared problem solving, reduce professional isolation, provide a proxy of supervision and encourage self-direction, improve workplace confidence minimise training fatigue, and maximise application of training.

\section{Method}

Utilising the researchers existing relationships, senior medical supply workers in Pacific Island Countries were invited to join the Pacific Medical Supply Workers Buddy Network. Further invitations were sent as members identified suitable colleagues to join. Members committed to sharing work achievements and challenges with each other via email, the Network website http://pacificmed.net/ and a monthly newsletter. Quantitative and qualitative evaluation of satisfaction with, and performance of, the Network was undertaken at 6 and 12 months.

\section{Results}

Eleven newsletters have been published, based on approximately 2000 communication episodes. On a 7 point scale ( $1=$ not at all, $4=$ neutral, $7=$ very much) 9 of 23 members report that their initial hopes of the Network have been met "a lot" (5.9/7).

In descending order of positive response, members consider that the Buddy Network:
1. reduces professional isolation (6.2/7) (a lot)

2. improves workplace confidence (5.7/7) (a lot)

3. maximises application of training (5.3/7) (a little)

4. encourages shared problem solving (5.2/7) (a little)

5. provides a proxy of supervision and encourages self-direction (5.2/7) (a little)

6. minimises training fatigue (4.2/7) (neutral)

\section{Discussion}

The Network was established to help senior medical supply workers "learn from each other's challenges and experiences - approaching our situation with new ideas". Current membership includes 34 senior workers from 15 countries, representing medical supply systems serving more than 9 million people. The Network has shown positive influences on many aspects of member's work, with the expectation that this will improve their ability to manage their countries medical supply systems and thereby improve access to medical supplies in their countries. Members consider unequal member contribution and difficult access to the website as the main areas requiring improvement in the Network.

\section{Lessons learned}

- Email is the preferred method of communication.

- The potential website benefits (resource library, chat, discussion forum) have not yet been realised due to restricted or expensive internet access and some unfamiliarity with technology.

- Active members expect greater contributions by less active members and look to the researchers to drive this.

\footnotetext{
* Correspondence: ben.gilbert@canberra.edu.au

'University of Canberra, Canberra, Australia

Full list of author information is available at the end of the article
} 


\section{Authors' details}

${ }^{1}$ University of Canberra, Canberra, Australia. ${ }^{2}$ People that Deliver,

Copenhagen, Denmark.

Published: 17 December 2014

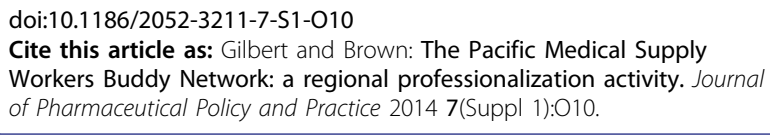

Submit your next manuscript to BioMed Central and take full advantage of:

- Convenient online submission

- Thorough peer review

- No space constraints or color figure charges

- Immediate publication on acceptance

- Inclusion in PubMed, CAS, Scopus and Google Scholar

- Research which is freely available for redistribution 